\title{
Corpora of Vietnamese Texts: Lexical effects of intended audience and publication place
}

\author{
Giang Pham, Kathrin Kohnert, and Edward Carney \\ University of Minnesota, Minneapolis, Minnesota
}

\begin{abstract}
This article has two primary aims. The first is to introduce a new Vietnamese text-based corpus. The Corpora of Vietnamese Texts (CVT; Tang, 2006a) consists of approximately 1 million words drawn from newspapers and children's literature, and is available online at www.vnspeechtherapy.com/vi/CVT. The second aim is to investigate potential differences in lexical frequency and distributional characteristics in the CVT on the basis of place of publication (Vietnam or Western countries) and intended audience: adult-directed texts (newspapers) or child-directed texts (children's literature). We found clear differences between adult- and child-directed texts, particularly in the distributional frequencies of pronouns or kinship terms, which were more frequent in children's literature. Within child- and adult-directed texts, lexical characteristics did not differ on the basis of place of publication. Implications of these findings for future research are discussed.
\end{abstract}

Vietnamese is an Asian tonal language with approximately 80 million speakers globally (D. H. Nguyen, 2001). Although speakers of this language are primarily located in Vietnam (70-73 million speakers), there are also large numbers of Vietnamese speakers in Western countries, including Australia, Germany, France, and the Netherlands. There are an estimated 1.12 million Vietnamese in the United States, making this group the fourth largest Asian American population, following Chinese, Filipinos, and Asian Indians (Reeves \& Bennett, 2004). Although useful information is available describing sounds, tones, lexical categories, and grammatical aspects of Vietnamese (e.g., D. H. Nguyen, 1997), only very limited information is available regarding frequency or distributional characteristics of these linguistic units. Large corpora have been collected on English (e.g., Kučera \& Francis, 1967), as well as many other languages (for a review, see Wilson, Archer, \& Rayson, 2006). When they are large enough in number and have an adequate variety of samples (according to one's purpose), language corpora may reveal much information about the linguistic patterns that are exemplars of "real life" language use (McEnery \& Wilson, 2001).

In this article, we introduce the Corpora of Vietnamese Texts (CVT; Tang, 2006a) and compare it with the single existing corpus in Vietnamese (D. D. Nguyen, 1980). We then use the new data source to examine potential influences of publication place as well as intended audience on lexical measures. Because the CVT is composed of data published both inside and outside of Vietnam, and from adult- and child-directed texts, this type of analysis is seen as an important first step to qualify its practical utility. Preliminary to coding words into lexical classes, it is important to de- termine whether overall frequency counts are distributed equivalently across different source data included in the text database. This is true in any language, but takes on additional importance when dealing both with text that can be considered to be in a majority language (originally written in Vietnamese and published in Vietnam) as well as text in which the language of interest has minority language status (written or translated into Vietnamese and published in a Western country). In these situations, some of the available text may be translated from English into Vietnamese, as is often the case with children's literature. In other cases, geographic- and usage-based differences in Vietnamese across countries may result in quantitative as well as qualitative differences in language. We used the CVT to investigate potential differences and similarities in lexical frequency and distributional characteristics on the basis of place of publication (Vietnam or Western countries) and text genre (newspapers or children's books). We begin with an overview of the Vietnamese language, focusing on those aspects most relevant to corpora data collection and lexical analysis.

\section{Characteristics of Vietnamese}

Vietnamese is an isolating language, in that it does not use bound morphemes to express grammatical features such as number (singular/plural) and tense. Instead of bound morphemes, Vietnamese grammar relies on word order and function words (K. L. Nguyen, 2004). For comprehensive descriptions of Vietnamese across language domains, see D. H. Nguyen (1997) and Tang (2006b).

Modern Vietnamese script uses the Vietnamese alphabet quốc ngü', or "national script," based on a Romanized script expanded with diacritics to mark certain vowels

\section{G.Pham, tangx098@umn.edu}


and tones. Vietnamese orthography is transparent, with a nearly one-to-one grapheme-to-phoneme correspondence. For the analysis of text corpora, particularly at the phonological level, this consistent sound-symbol correspondence represents a significant advantage over other languages that have a more opaque correspondence between sounds and written symbols. For instance, sound frequency counts may be conducted on the basis of written texts rather than transcriptions of spoken language.

Vietnamese was once erroneously considered to be a monosyllabic language, with each word equal to one syllable (e.g., Thompson, 1965). It is now recognized that Vietnamese words may consist of one, two, three, or even four syllables (D. H. Nguyen, 1997). Although a Vietnamese word may contain more than one syllable, single syllables continue to be separated in the writing system. That is, the spacing between each syllable creates the illusion that each syllable is one word. For instance, the single word "clock" is made up of two syllables separated by a space: dồng hồ. With regard to meaning, it is often difficult to define what constitutes a word in Vietnamese. For instance, although me con may be translated into two English words ("mother" "child"), most Vietnamese linguists consider it one compound word (e.g., Do, 1981), because it signifies a single concept of mother-child relations. The ongoing debate about the definition of a "word," combined with the orthographically separated syllables in Vietnamese, poses a significant challenge for the creation of language corpora. Currently available corpora software programs are able to calculate frequency counts based on lexical form, but are not able to parse forms into word units based on meaning.

At the lexical-semantic level, words in Vietnamese as well as English can be divided into content and function words. Content words carry semantic meaning, whereas function words relate content words to each other (Stubbs, 2001). Content words for both English and Vietnamese may be further divided into word classes, such as nouns, verbs, and adjectives. In Vietnamese as well as English, lexical forms may have more than one meaning or belong to more than one word class, with meaning and grammatical class disambiguated by sentence context. In English, words may keep the same form (e.g., tree bark vs. dogs bark) or change in form (e.g., sit in the chair vs. he chaired the meeting) when changing word class (see Bauer, 1983). Vietnamese words change in word class without altering form (Tang, 2006b), which poses a challenge for corpora analyses. Word forms that may serve as nouns as well as verbs, for instance, can only be distinguished within the context of each sentence. No software programs are available to parse lexical items into separate word classes in Vietnamese. Needless to say, manual calculations of this type would be quite onerous for corpora containing millions of words.

Both Vietnamese and English have pronouns to substitute for nouns or noun phrases. An important language characteristic of Vietnamese that is not found in English is the use of kinship terms. Most Vietnamese kinship terms may be used as pronouns to reflect age, status, and gender of both speaker and listener (Tang, 2006b). Kin- ship terms that serve as pronouns are used with persons within and outside of one's family (Luong, 1990). There are only a few pronouns that are not kinship terms that can be used in a general sense, such as tôi ("I"). Within the family pronominal, kinship terms distinguish between paternal and maternal sides of the family, age, gender, and blood relations as opposed to in-law status (K. L. Nguyen, 2004). Unfamiliar speakers and listeners also refer to each other and themselves differently depending on social factors, including age and status. For example, a person who is approximately the age of one's uncle or aunt could be addressed as chu or cô, respectively, while referring to oneself as cháu ("niece/nephew") in the northern dialect or con ("son/daughter") in the southern dialect. When meeting someone approximately the age of one's older sister, one may refer to himself or herself as em ("younger sibling") and address the speaker as chi ("older sister"). When the relative ages of the speaker and listener are not known, it is common to address the listener with pronouns that indicate older age, as a sign of respect, because older age is associated with higher status (Luong, 1990).

Unlike English pronouns, Vietnamese pronouns do not indicate number. In order to indicate plurality in Vietnamese, a quantifier is added before the pronoun. For example, các ("some") is added before chú ("uncle") to indicate more than one male who is approximately the age of one's uncle: các chú. Vietnamese pronouns do not indicate person (speaker, listener, or third party), which poses another challenge for analyzing corpora data. Although frequency counts can be conducted at the form level, the meaning of the person reference can only be interpreted within the sentence or paragraph context. In English, there are different pronouns that indicate sentential subject and predicate positions (e.g., "she" vs. "her"). Vietnamese pronouns do not change form and therefore do not indicate subject and predicate position.

Vietnamese uses affixation, compounding, and reduplication to create new meanings from existing lexical forms. Affixation is the process by which a language attaches meaningful linguistic units (bound morphemes) to a word to change its meaning. Examples of affixation in English are un- in unreal or -ful in wonderful. Vietnamese uses prefixes and suffixes as well, although they are used differently. Rather than attaching to the word itself, affixes appear separate from the word. For instance, the prefix bán ("half, semi") appears before cầu ("sphere") to create the word bán cầu ("hemisphere") The suffix hóa ("-ize, -fy") appears after Việt Nam ("Vietnam") to create the word Việt (Nam) hóa ("to Vietnamize"; D. H. Nguyen, 1997). Since affixes are not attached to the word in Vietnamese, this may affect word-frequency counts in Vietnamese corpora data.

Compounding, the process of combining two or more words to create a new word, occurs in both Vietnamese and English. English examples include "armchair" and "beehive." Vietnamese examples include hải quân [(ocean armed-force) "(the) navy"] and bàn ghế [(table chair) "furniture"]. Traditionally, Vietnamese compound words appear as two or more separate syllables in the writing system, which, as mentioned earlier, poses a challenge for word-frequency counts based on large corpora. 
In addition to compounding by combining two different words, compounding can also be achieved by repeating or reduplicating lexical forms. Compounding by reduplication rarely occurs in English and is primarily used in words that reflect sounds, or noises, such as "click clack" (Thompson, 1965). Vietnamese frequently uses reduplication in content words, such as verbs, adjectives, and nouns. Reduplications may consist of the replication of an entire syllable or of its individual components such as the rime, initial consonant sound, or principal vowel, and serve various semantic functions (G. T. Nguyen, 2003). Reduplication of a verb typically indicates movement. For instance, gật [dầu ] ["to nod (one's head)"] can be reduplicated to indicate a continuous nodding motion: gột gột dầu. In the case of adjectives, reduplication can imply a lesser degree of a quality. For example, color terms such as "green" (xanh), can indicate a lighter shade when the word is reduplicated, xanh xanh. Certain nouns can be reduplicated to indicate reoccurrence or multiple instances, such as ngày ngày ("day day"), which implies many days or all days (C. T. Nguyen, 1999; D. H. Nguyen, 1997; G. T. Nguyen, 2003; K. L. Nguyen, 2004). Reduplications may affect the accuracy of lexical counts since they are typically thought of as one word but would be counted twice. (For additional information on characteristics of Vietnamese, see Tang, 2006b.)

\section{CVT Collection and Characteristics}

The CVT is composed of two different text genres, one typically directed toward adults (newspaper articles) and the other typically directed toward children (children's books). Because a general purpose of the CVT is to investigate language use in Vietnamese Americans as well as Vietnamese nationals, texts published in Vietnam as well as in Western countries were collected. Sources and word counts for these different text genres (adult directed or child directed) and publication places (Vietnam or other) are summarized in Table 1. A complete list of all sources is available online at vnspeechtherapy.com/vi/CVT/3_ CVT_The\%20Basics.htm.

The first text genre is made up of online Vietnamese newspaper articles from a total of four sources: two sources published in Vietnam and two sources published in the United States. Articles were collected from April to July of 2006. Article topics included world and national news, politics, health and medicine, education, current events, sports, editorials, economics, science and technology, relaxation, love, and daily life. Advertisements and comics were excluded from the corpus. Adult-directed texts were in electronic format and were collected from online newspaper sources; full articles were selected and pasted into a word processing program. As shown in Table 1, the total word count for newspaper articles is 851,174 , making up $80 \%$ of the CVT. Of this total, 265,282 words (31\%) come from articles published in Vietnam and 585,892 words $(69 \%)$ were from articles published in the U.S.

The second genre consists of over 350 children's books, varying in reading level from preschool through fifth grade, including what are typically referred to as picture books, repetitive books, and folklore stories. Chapter books and comics were excluded from the corpus. Children's books
Table 1

CVT Composition and Word Counts

\begin{tabular}{lccr}
\hline Publication Place & $\begin{array}{c}\text { Newspaper } \\
\text { Articles }\end{array}$ & $\begin{array}{c}\text { Children's } \\
\text { Literature }\end{array}$ & \multicolumn{1}{c}{$\begin{array}{c}\text { Total } \\
\text { Words }\end{array}$} \\
\hline Vietnam published & 267,905 & 163,543 & 431,448 \\
Other published & 588,619 & 43,845 & 632,464 \\
Total words & 856,524 & 207,388 & $1,063,912$ \\
\hline
\end{tabular}

Note-Newspaper articles were collected from several sections of two newspapers published in Vietnam (Thanh Niên, Tuổi Tré) and two newspapers published in the United States $(V O A, V N N)$ in the year 2006. Children's literature consisted of 279 picture books published in Vietnam and 78 picture books published in Western countries.

were collected from elementary schools, libraries, and bookstores in the United States and Vietnam. Access to children's books was more limited, because they were not available in electronic format. The vast majority of books were published in Vietnam, because of the relatively limited availability of children's books in Vietnamese from other countries. Picture books that were published outside of Vietnam were primarily from the United States and England, with a few books published in Australia and New Zealand. Child-directed texts made up $20 \%$ of the CVT (see Table 1). In the child-directed texts, there were four times as many words from books published in Vietnam $(163,543$ words, or $79 \%)$ as there were words from books published in Western countries $(43,845$ words, or $21 \%)$, because of the limited amount of children's literature in Vietnamese available in English-speaking countries. In order to obtain relatively similar numbers of words across place of publication, we used almost twice as many words from adult-directed texts published in Western countries as we did words from adult-directed texts from Vietnam. Childdirected texts were manually typed into a word processor, since access to text-scanning software for Vietnamese was not available at that time (but see VnDOCR, 2006).

From a word processing program, all of the texts were then formatted for MonoConc Professional 2.2 (Barlow,

Table 2

Comparison of Vietnamese Corpora

\begin{tabular}{lll}
\hline \multicolumn{1}{c}{ Characteristic } & D. D. Nguyen (1980) & \multicolumn{1}{c}{ Tang (2006a) } \\
\hline Type & Text & Text \\
Size & 524,500 words & $1,063,912$ words \\
Format & Paper & Electronic \\
Description & Consists of newspaper & Consists of news- \\
& articles, poetry, theat- & paper articles from \\
& rical works, children's & 2006 and children's \\
& literature, and Ho Chi & picture books from \\
& Minh's writings from & 1976 to 2006 \\
& 1956 to 1972 &
\end{tabular}

Coding level Separates lexical Vietramese-specific frequency by catego- vowels and tones ries including nouns, coded to be read by verbs, adjectives, MonoConc Profesnumbers, connecting sional 2.2 concorwords, proper nouns, dance program and so on

Overlap of top 100 - 67 $\begin{array}{lll}\text { Rank correlation } & - & .660^{*}\end{array}$ aBased on common words of the 100 most frequent words of each corpus $(n=67) . \quad p<.0005$ in a one-tailed analysis. 
2003), a concordance software program. Although MonoConc Professional 2.2 had the capability to read a variety of languages, the software was not able to read Vietnamese. Therefore, certain tones and vowels specific to Vietnamese were numerically coded using the find and replace function of the word processing program (for a complete list of codes, see Tang, 2006a). It should be noted that the word count electronically calculated by the word processor was 1,055,617, whereas MonoConc Professional 2.2 calculated a total of $1,063,912$. This minor discrepancy $(0.78 \%)$ may be due to the fact that neither the word processor nor the concordance program was programmed to count words in Vietnamese. Since we used the concordance program throughout the analyses, we used the word total of $1,063,912$, calculated by the same program, for consistency.

There were notable differences in sample size across the four corpora. Sample sizes for newspapers were larger than were sample sizes for children's literature because newspapers were available electronically; access to children's books was limited to those available in libraries, bookstores, and elementary schools. Also, a text-scanning program for Vietnamese was not available at the time. The time needed to manually type children's books into a word processor was another practical limitation for the children's literature sample. Children's books that were available were primarily published in Vietnam; the sample size of children's books published in other countries was much smaller, by comparison. Tang (2006a) collected a larger sample size of newspapers published in other countries in order to counterbalance unequal sample sizes in children's literature. The following is a comparison of the CVT with an older Vietnamese corpus.

\section{Existing Corpora Datalin Vietnamese}

Existing corpora data in Vietnamese are sparse. Prior to the CVT (Tang, 2006a), there was one published text-based corpus, by D. D. Nguyen (1980). There are no available corpora on spoken Vietnamese. The primary purpose of the D. D. Nguyen corpus was to identify fundamental Vietnamese vocabulary to contribute to the field of lexicology. Words were manually parsed, and frequency counts were divided into word classes on the basis of sentence meaning. The result of corpus analysis was a summary of basic Vietnamese vocabulary, with French translations. Table 2 summarizes general characteristics of the D. D. Nguyen corpus as compared with the CVT. Differences between the two corpora include size, format, and composition. The D. D. Nguyen corpus consists of 524,500 words from a variety of text genres, including novels, poetry, theatrical works, children's literature, newspaper articles, and Ho Chi Minh's writings. The D. D. Nguyen corpus was made up of texts published between 1956 and 1972 . Over $66 \%(350,400 / 524,500$ words $)$ of the corpus by D. D. Nguyen consists of literary works, such as novels, poetry, theatrical works, and children's literature. Children's literature made up close to $14 \%(48,500 / 350,400)$ of the literary texts and $9 \%(48,500 / 524,500)$ of the entire corpus. Apart from the sample of children's literature, all text genres were for an adult audience. The CVT (Tang, 2006a) consists of 1,063,912 words from children's literature and newspaper articles. The children's literature was published between 1976 and 2006, and the newspaper articles were
Table 3

Overlap From 100 Most Frequent Words of the CVT

\begin{tabular}{lc}
\hline Comparison & Shared Words \\
\hline Adult VN-Adult Other & 78 \\
Child VN-Child Other & 80 \\
Adult VN-Child VN & 57 \\
Adult Other-Child Other & 53 \\
Adult VN-Child Other & 56 \\
Adult Other-Child VN & 56 \\
\hline
\end{tabular}

Note-Displays the number of words shared across subcorpora.

all published in 2006. The D. D. Nguyen corpus is available in paper format, whereas the CVT is in electronic format (vnspeechtherapy.com/vi/CVT/ResearchChude.htm).

Although the two corpora differ in many ways, they are comparable in general word frequencies. Appendix A lists words shared between the CVT (Tang, 2006a) and D. D. Nguyen (1980), based on the 100 most frequent words of each corpus $(n=67)$. A Spearman rank correlation was calculated as one measure of corpus similarity. There was a significant positive correlation between the two corpora $(r=.66, p<.001)$, indicating that not only were the vast majority of words shared across corpora, but the frequency rankings were also similar.

In Appendix A, words are listed in descending order of $\log$ likelihood (LL) ratios with corresponding raw frequency counts and frequency rankings from each corpus. Rayson and Garside (2000) proposed using LL ratios for frequency profiling when comparing corpora, to estimate the relative frequency difference between two corpora. High LL ratios indicate great disparities in frequency rankings, whereas low LL ratios indicate high similarity in frequency ranking order across corpora. Rayson and Garside calculated $L L$ ratios with the following equation: $2 *\{[a * \ln (a / E 1)]+[b * \ln (b / E 2)]\}$, where $a=$ the frequency count of a word from Corpus $1, b=$ the frequency count of the same word from Corpus 2, and $E$ is the expected value that is calculated using the following equation: $E_{i}=\left(N_{i} \Sigma O_{i}\right) /\left(\Sigma N_{i}\right)$. The combination of frequency ranking and LL ratios further informs our understanding of similarities and differences between the two corpora. For example, the kinship term anh ("older brother") occurs frequently in both Tang (2006a) and D. D. Nguyen (1980) but differs substantially in frequency ranks (64 and 9, respectively), yielding the highest LL ratio of 13,533.08. At the other extreme, the verb có ("to have") greatly differs in raw frequency across corpora but is ranked third in each corpus, with a corresponding LL ratio $<0.01$. Another example is the word $v a$ ("and"), with the highest frequency in both corpora but also a relatively high $L L$ ratio, indicating that its

Table 4

Spearman Rank Correlations Across Corpora

\begin{tabular}{lcccc}
\hline Corpus & Adult VN & Adult Other & Child VN & Child Other \\
\hline Adult VN & - & .85 & .40 & .52 \\
Adult O & & - & .46 & .52 \\
Child VN & & & - & .79 \\
Child O & & & & - \\
\hline
\end{tabular}

Note-Based on the 100 most frequent words that occurred across all genres and places of publication $(n=46)$. All correlations are statistically significant at $p<.005$, on the basis of one-tailed analysis. 
Table 5

Estimated Distributions of Word Classes Across Corpora

\begin{tabular}{|c|c|c|c|c|c|c|c|c|}
\hline \multirow[b]{2}{*}{ Word Class } & \multicolumn{2}{|c|}{ Adult Vietnam } & \multicolumn{2}{|c|}{ Adult Other } & \multicolumn{2}{|c|}{ Child Vietnam } & \multicolumn{2}{|c|}{ Child Other } \\
\hline & Raw & $\%$ & Raw & $\%$ & Raw & $\%$ & Raw & $\%$ \\
\hline ouns & 21,879 & 38.8 & 8,173 & 43.80 & 30, & 47.43 & 7,768 & 38.96 \\
\hline erbs & & & & & & & & 26 \\
\hline tives & 14 , & 25 & 4,4 & 2 & 14 & 22.06 & 4,831 & 24.24 \\
\hline ors & 2,44 & 4. & 866 & 4.64 & 1 , & 1.72 & 935 & 4.69 \\
\hline ins $^{a}$ & 1,697 & 3.0 & 210 & 1.13 & 18,291 & 28.02 & 3,412 & 17.11 \\
\hline bs & 9,948 & 17.67 & 2,369 & 12.70 & 10,743 & 16.46 & 3,315 & 16.63 \\
\hline Conjunctions & 8,022 & 14.25 & 2,656 & 14.23 & 6,219 & 9.53 & 2,943 & 14.76 \\
\hline Prepositions & 6,172 & 10.96 & 2,314 & 12.40 & 2,696 & 4.13 & 1,584 & 7.95 \\
\hline Totalb & 85,323 & 151.55 & 27,417 & 146.93 & 108,722 & 166.56 & 32,016 & 160.60 \\
\hline ubcorpus totale & 56,295 & & 18,659 & & 65,272 & & 19,936 & \\
\hline
\end{tabular}

Note-Word class categorization was based on $\operatorname{Tan}(1994)$ and the Vietnamese Dictionary and Translation (2006). "Most pronouns are also Vietnamese kinship terms. bMany items may belong to more than one word class and were counted for each possible word class. cBased on the 100 most frequent words in each subcorpus.

use or relative "importance" may vary across corpora. The CVT by Tang (2006a) contributes to Vietnamese language corpora with the addition of current texts (1976-2006), electronic accessibility, and larger samples of daily language use (e.g., newspapers vs. literature). The composition of the CVT is further described in the following section and is the focus of all subsequent analysis.

\section{Analyses of the 100 Most Frequent Words of the CVT}

The CVT was divided into four separate corpora for comparison: newspapers published in Vietnam (Adult VN), newspapers published outside Vietnam (Adult Other), children's books published in Vietnam (Child VN), and children's books published outside Vietnam (Child Other). Given that the CVT was not parsed or tagged, we performed preliminary analyses on the 100 most frequent words of each subcorpus to investigate the potential composition of the entire corpus (see Appendix B for complete lists). Table 3 displays the number of words shared across intended audience and place of publication on the basis of the 100 most frequent words of each subcorpus. Texts directed toward adults (Adult VN, Adult Other) shared a relatively high number of words (78 of 100), and texts typically directed toward children shared a similar number of words $(80$ of 100$)$. Fewer words were shared across texts directed to different audiences (adult vs. child), ranging from 53 to 57 of 100 words.

One-tailed Spearman rank correlations were calculated to examine how frequent words were ranked across subcorpora (see Table 4). All correlations were statistically significant $(p<.005)$, indicating a relationship between the ranking of frequent words of each subcorpus on the basis of sampling of the 100 most common words. This finding seemed reasonable, given that the CVT is made up of one language (Vietnamese). It was important to note that texts directed toward adults were highly correlated $(r=.850)$, texts directed toward children were highly correlated $(r=$ .791), whereas texts intended for different audiences (adult, child) exhibited relatively lower correlations of around .50. Raw frequency counts of shared words (Table 3 ) as well as Spearman rank correlations (Table 4) highlighted overall differences between adult- and child-directed texts at the lexical level. However, these measures did not indicate differences on the basis of place of publication.

To further investigate lexical characteristics across subcorpora, we estimated distributions of word classes on the basis of the 100 most frequent words (see Table 5). The 100 most frequent words were listed separately for each subcorpus. Words were then classified into general categories of nouns, verbs, adjectives, numerators, pronouns, adverbs, conjunctions, and prepositions. As mentioned earlier, parsing tools were not available for Vietnamese, and manual calculations based on line-by-line sentential context were not feasible in this large sample. Therefore, in this analysis, words that could belong to more than one word class were counted in each possible category; total percentages were greater than $100 \%$. Table 5 displays estimated distributions across word class in raw frequency counts and percentages.

As shown in Table 5, the most common word classes across all subcorpora were nouns, accounting for approximately $40 \%$ of words, followed by verbs (about $35 \%$ ), and adjectives (about $25 \%$ ). Similarities in proportion of the three main word classes indicated a consistent level of major word classes across subcorpora.

Table 6

Number of 100 Most Frequent Words That Belong to One or More Word Classes

\begin{tabular}{ccccc}
\hline Number of Word Classes & Adult VN & Adult Other & Child VN & Child Other \\
\hline 1 & 60 & 63 & 51 & 52 \\
2 & 32 & 29 & 36 & 35 \\
3 & 8 & 8 & 13 & 13 \\
\hline
\end{tabular}


This agreement can also be seen in the number of words that belong to one or more word classes (see Table 6). Across subcorpora, the number of words that belonged to a single word class ranged from 51-63 of 100; words that potentially belonged to two word classes ranged from 29-36 of 100; and words that potentially belonged to three word classes ranged from 8-13 of 100. These estimations suggested that for certain types of corpus analyses, it may be possible to collapse across subcorpora to investigate major word classes such as nouns, verbs, and adjectives.

At the same time, differences between adult-directed and child-directed texts suggest that the CVT should be divided for certain analyses that could be unduly influenced by intended audience. For instance, the proportion of pronouns/kinship terms and prepositions differed between adult-directed and child-directed texts (see Table 5). The occurrence of pronouns/kinship terms ranged from $17 \%-28 \%$ in child-directed texts (children's literature), whereas they occurred in only $1 \%-3 \%$ of adult-directed texts (newspapers). A possible explanation is that kinship terms are often used in children's books with human or animal characters, such as chú mèo [(uncle cat) "Mr. Cat"]. In addition, there may be more dialogue in children's books, in which kinship terms are used to refer to the speakers and listeners. As shown in Table 5, prepositions occurred more often in adultdirected texts (11\%) than in child-directed texts (6\%). A possible explanation is that newspapers describe events in which explicit details of location and transactions are needed.

\section{Summary and Future Research}

The CVT database represents a significant addition to Vietnamese corpora in part due to its large sample size (over 1 million words), current content (years 1976-2006), inclusion of large samples of daily language use (i.e., newspapers), and electronic accessibility (www.vnspeechtherapy $. \mathrm{com} / \mathrm{vi} / \mathrm{CVT}$ ). It is a tool that will allow systematic investigation of frequency and distributional characteristics of the Vietnamese language at phoneme, word, and sentence levels. Results of the lexical analyses described here suggested that the CVT may be collapsed for linguistic analyses on general word classes including nouns, verbs, and adjectives. On the other hand, for certain types of linguistic analyses, such as investigating the role of kinship terms, researchers should consider the impact of genre type. The present analysis revealed no significant differences for language produced or published in the majority versus minority language countries. This null finding supports collapsing the CVT across place of publication. However, it is also possible that place of publication will have a greater influence at other language levels. One limitation of these analyses is that frequency counts were based on syllable forms. As mentioned earlier, the concept of "word" is an ongoing debate in Vietnamese linguistics. Furthermore, no parsing software is available to identify Vietnamese word units. Future parsing tools may enable deeper lexical analyses that include more accurate lexical counts as well as investigation of compound words and the phenomenon of reduplication.

Frequency and distributional information at sound, word, tone, and grammatical levels is needed for a variety of pedagogical, theoretical, and experimental reasons (Thomas \& Short, 1996). For example, to develop stimuli that will allow researchers to profile or test selected aspects of language in individuals who learn Vietnamese as a first or primary language, information regarding frequency and distributional characteristics of linguistic features is needed to develop stimuli for empirical validation and elaboration. The collection and analysis of corpora data are essential to understanding language and language use.

\section{AUTHOR NOTE}

Funding for this project was provided by the Graduate Research Partnership Program at the University of Minnesota and was awarded to the first author under the faculty mentorship of the second author. We thank Hai Anh Nguyen, Xuan Tran Tang, and Tien Pham, who helped manually type children's books for the children's literature subcorpus. We thank Pui Fong Kan, Mahmoud Sadrai, and Brian Gordon for technical assistance with computer software for corpus analysis. We thank the Center for Cognitive Processes in Language for the use of equipment. Correspondence concerning this article should be addressed to G. Pham (formerly G. Tang), Department of Speech-Language-Hearing Sciences, 115 Shevlin Hall, 164 Pillsbury Drive SE, University of Minnesota, Minneapolis, MN 55455 (e-mail: tangx098@umn.edu) or to K. Kohnert (e-mail: kohne005@umn.edu).

\section{REFERENCES}

Barlow, M. (2003). MonoConc Professional 2.2: A professional concordance program [Computer software]. Houston, TX: Athelstan.

BAUER, L. (1983). English word-formation. Cambridge: Cambridge University Press.

Do, C. H. (1981). Tì' vưng ngũu' nghĩa tiểng Việt [Vietnamese lexicosemantics]. Hà Nội: Nhà Xuất Bản Giáo Dục.

KUCERA, H., \& FrANCIS, W. N.(1967). Computational analysis of presentday American English. Providence, RI: Brown University Press.

LuONG, H. V. (1990). Discursive practices and linguistic meanings: The Vietnamese system of person reference. Philadelphia: Benjamins.

MCENERY, T., \& WILSON, A. (2001). Corpus linguistics: An introduction (2nd ed.). Edinburgh: Edinburgh University Press.

NGUYEN, C. T. (1999). Ngũ' pháp tiểng Việt, in lấn thu' sáu [Vietnamese grammar, 6th ed.]. Hà Nội: Nhà Xuất Bản Đại Học Quốc Gia.

NGUYEN, D. D. (1980). Dictionnaine de fréquence du Vietnamien [Frequency dictionary of Vietnamese]. Paris: Université de Paris.

NGUYEN, D. H. (1997). Vietnamese. Amsterdam: Benjamins.

NGuYen, D. H. (2001). Vietnamese. In J. Garry \& C. Rubino (Eds.), Facts about the world's languages: An encyclopedia of the world's major languages, past and present (pp. 794-796). New York: Wilson.

NGUYEN, G. T. (2003). Tù' vưng học tiêng Việt, tài bản lần thư' tu' [Vietnamese semantics, 4th ed.]. Ho Chi Minh City: Nhà Xuất Bản Giáo Dục.

NGUYEN, K. L. (2004). Giáo trình tiếng Việt II [Teachings on Vietnamese II]. Huế: Đại Học Huế Trung Tâm Tạo Tú Xa.

RAYSON, P., \& GARSIDE, R. (2000, October). Comparing corpora using frequency profiling. Paper presented at the Workshop on Comparing Corpora and the 38th Annual Meeting of the Association of Computational Linguistics, Hong Kong.

ReEves, T. J., \& BenNetT, C. E. (2004). We the people: Asians in the United States. Census 2000 Special Report (U.S. Census Bureau Report No. ASI 2004 2326-31. 16). Washington, DC: U.S. Department of Commerce, Economics, and Statistics Administration.

STUBBS, M. (2001). Words and phrases: Corpus studies of lexical semantics. Oxford: Blackwell.

TAN, V. (1994). Tü' điển tiếng Việt [Vietnamese dictionary]. Hà Nội: Nhà Xuất Bản Khoa Học Xã Hội. 
TANG, G. (2006a). Corpora of Vietnamese Texts. Retrieved October 7, 2006, from www.vnspeechtherapy.com/vi/CVT.

TANG, G. (2006b). Cross-linguistic analysis of Vietnamese and English with implications for Vietnamese language acquisition and maintenance in the United States. Journal of Southeast Asian-American Education \& Advancement, 2, 1-33.

ThOMAs, J., \& SHORT, M. (EDs.) (1996). Using corpora for language research: Studies in honour of Geoffrey Leech. London: Longman.

ThOMpson, L. (1965). A Vietnamese grammar. Seattle: University of Washington Press.

VIETNAMESE DICTIONARY AND TRANSLATION (2006). Retrieved January 15,2007 , from vdict.com/.

VNDOCR (2006). Version 2.2 [Vietnamese text-scanning software]. Retrieved October 1, 2006, from www.vndocr.itgo.com/.

Wilson, A., ARCHER, D., \& RAYsON, P. (2006). Corpus linguistics anound the world. New York: Rodopi.

APPENDIX A

Shared Words Across Tang (2006a) and D. D. Nguyen (1980)

\begin{tabular}{|c|c|c|c|c|c|}
\hline \multirow[b]{2}{*}{ Item } & \multicolumn{2}{|c|}{ Tang (2006a) } & \multicolumn{2}{|c|}{ D. D. Nguyen (1980) } & \multirow[b]{2}{*}{ LL } \\
\hline & Frequency & Rank & Frequency & Rank & \\
\hline anh & 2,659 & 64 & 3,854 & 9 & $13,533.08$ \\
\hline ta & 690 & 72 & 2,720 & 21 & $3,146.034$ \\
\hline đi & 3,495 & 37 & 3,408 & 13 & 785.4055 \\
\hline nhũrng & 6,583 & 13 & 5,236 & 5 & 649.3777 \\
\hline khi & 4,127 & 29 & 1,053 & 76 & 410.6416 \\
\hline lên & 2,979 & 56 & 2,501 & 25 & 375.153 \\
\hline đế & 5,303 & 15 & 1,543 & 45 & 363.4923 \\
\hline ông & 4,315 & 23 & 1,235 & 62 & 311.7079 \\
\hline phải & 3,872 & 34 & 2,906 & 18 & 285.4529 \\
\hline nhà & 4,155 & 28 & 1,241 & 61 & 260.989 \\
\hline thì & 3,152 & 46 & 2,418 & 28 & 260.381 \\
\hline mới $\mathrm{i}$ & 1,887 & 99 & 1,617 & 43 & 259.2179 \\
\hline ơ & 4,204 & 27 & 3,052 & 16 & 258.002 \\
\hline mà & 2,974 & 57 & 2,278 & 31 & 243.7917 \\
\hline còn & 3,048 & 51 & 2,257 & 32 & 208.9722 \\
\hline làm & 4,044 & 32 & 2,825 & 19 & 197.0004 \\
\hline tôi & 4,278 & 25 & 2,916 & 17 & 177.6291 \\
\hline rồi & 1,862 & 100 & 1,465 & 47 & 174.3677 \\
\hline mình & 2,400 & 71 & 1,768 & 39 & 159.9267 \\
\hline thế & 3,341 & 42 & 1,074 & 74 & 159.1296 \\
\hline sẽ & 3,385 & 40 & 1,108 & 70 & 149.3626 \\
\hline năm & 3,499 & 36 & 1,206 & 63 & 121.3333 \\
\hline và & 13,710 & 1 & 7,903 & 1 & 120.7843 \\
\hline các & 8,803 & 8 & 5,257 & 4 & 118.901 \\
\hline bị & 3,451 & 38 & 1,203 & 64 & 112.9223 \\
\hline trên & 3,113 & 48 & 2,074 & 35 & 110.2647 \\
\hline nước & 3,368 & 41 & 2,203 & 33 & 104.0976 \\
\hline đã & 8,047 & 10 & 4,771 & 7 & 100.2636 \\
\hline ra & 5,091 & 16 & 3,091 & 15 & 81.9014 \\
\hline thấy & 2,141 & 86 & 1,437 & 48 & 79.93346 \\
\hline này & 4,545 & 20 & 1,758 & 41 & 77.18171 \\
\hline dang & 2,237 & 83 & 1,470 & 46 & 71.60603 \\
\hline cũng & 4,295 & 24 & 2,601 & 24 & 67.30049 \\
\hline vào & 4,729 & 19 & 2,775 & 20 & 52.21448 \\
\hline cho & 8,807 & 7 & 3,814 & 11 & 45.4523 \\
\hline tù & 3,395 & 39 & 1,354 & 53 & 44.77509 \\
\hline sau & 2,720 & 60 & 1,060 & 75 & 43.5632 \\
\hline nào & 1,994 & 91 & 1,243 & 60 & 41.31653 \\
\hline theo & 2,507 & 70 & 974 & 81 & 41.13648 \\
\hline nói & 3,201 & 45 & 1,890 & 37 & 38.0248 \\
\hline cả & 2,680 & 62 & 1,577 & 44 & 30.58672 \\
\hline với & 5,723 & 14 & 2,481 & 26 & 29.08203 \\
\hline về & 4,274 & 26 & 2,419 & 27 & 29.05309 \\
\hline trong & 8,576 & 9 & 3,821 & 10 & 27.41079 \\
\hline nhu'ng & 3,068 & 49 & 1,762 & 40 & 25.71427 \\
\hline đầu & 2,724 & 59 & 1,129 & 68 & 24.58826 \\
\hline
\end{tabular}


APPENDIX A (Continued)

\begin{tabular}{lcccccc}
\hline & \multicolumn{2}{c}{ Tang (2006a) } & & \multicolumn{2}{c}{ D. D. Nguyen (1980) } & \\
\cline { 2 - 5 } \multicolumn{1}{c}{ Item } & Frequency & Rank & & Frequency & Rank & LL \\
\hline đến & 4,921 & 17 & 2,141 & 34 & 23.67577 \\
chỉ & 2,999 & 55 & 1,262 & 58 & 22.72962 \\
như & 4,334 & 22 & 2,410 & 29 & 22.18372 \\
là & 10,904 & 5 & 4,963 & 6 & 21.96329 \\
đây & 2,020 & 90 & 1,178 & 67 & 20.66833 \\
ngày & 3,059 & 50 & 1,307 & 56 & 19.09984 \\
trước & 1,910 & 98 & 1,109 & 69 & 18.4953 \\
lại & 4,085 & 31 & 1,801 & 38 & 15.82077 \\
của & 12,998 & 2 & 6,058 & 2 & 13.11715 \\
rất & 1,981 & 92 & 1,091 & 72 & 8.534645 \\
hợn & 2,185 & 84 & 965 & 82 & 8.209146 \\
qua & 2,099 & 87 & 941 & 88 & 5.934528 \\
nhiều & 3,021 & 53 & 1,377 & 51 & 5.872452 \\
người & 6,963 & 12 & 3,598 & 12 & 5.220412 \\
được & 6,990 & 11 & 3,309 & 14 & 3.714559 \\
đó & 3,924 & 33 & 1,961 & 36 & 0.241675 \\
không & 8,995 & 6 & 4,396 & 8 & 0.224307 \\
biết & 2,245 & 81 & 1,094 & 71 & 0.099147 \\
con & 4,857 & 18 & 2,408 & 30 & 0.051142 \\
việc & 2,621 & 65 & 1,286 & 57 & 0.019531 \\
có & 11,052 & 3 & 5,441 & 3 & 0.007005 \\
\hline
\end{tabular}

Note-Based on the 100 most frequent words of each corpus $(n=67)$. LL, log likelihood ratios, an estimate of the relative frequency difference between two corpora. High LL ratios indicate large differences in frequency rankings. Low $\mathrm{LL}$ ratios indicate high similarity in frequency ranking across corpora.

APPENDIX B

List of 100 Most Frequent Words in Each Subcorpus of the CVT

\begin{tabular}{|c|c|c|c|c|c|c|c|c|}
\hline & Adult VN & Freq & Adult $\mathrm{O}$ & Freq & Child VN & Freq & Child O & Freq \\
\hline 1 & anh & 691 & an & 406 & ăn & 593 & ăn & 136 \\
\hline 2 & bi & 687 & anh & 424 & ấy & 385 & anh & 213 \\
\hline 3 & biết & 610 & bị & 850 & anh & 642 & ba & 130 \\
\hline 4 & bộ & 627 & bộ & 420 & bà & 631 & bà & 172 \\
\hline 5 & cá & 559 & cả & 543 & bạn & 537 & bạn & 160 \\
\hline 6 & các & 2,231 & các & 1,806 & bác & 389 & bác & 149 \\
\hline 7 & chỉ & 930 & chỉ & 571 & bay & 311 & bé & 208 \\
\hline 8 & chinh & 656 & chính & 885 & bé & 661 & bên & 86 \\
\hline 9 & cho & 2,016 & cho & 1,579 & bi & 446 & biết & 118 \\
\hline 10 & có & 3,094 & chức & 403 & biết & 395 & cá & 97 \\
\hline 11 & $\cos ^{\circ}$ & 493 & chủ & 796 & cả & 577 & cả & 134 \\
\hline 12 & con & 643 & chúng & 453 & các & 728 & các & 182 \\
\hline 13 & còn & 754 & có & 1,712 & cái & 549 & cái & 231 \\
\hline 14 & công & 1,362 & cộng & 421 & cây & 515 & cho & 322 \\
\hline 15 & của & 3,229 & con & 424 & chạy & 335 & choi & 126 \\
\hline 16 & cũng & 1,075 & còn & 553 & chàng & 315 & chú & 229 \\
\hline 17 & dân & 541 & công & 1,115 & chi & 354 & chúng & 295 \\
\hline 18 & đã & 1,899 & của & 2,498 & chim & 355 & có & 502 \\
\hline 19 & đầu & 808 & cũng & 668 & cho & 1,289 & cô & 273 \\
\hline 20 & dang & 534 & dân & 1,491 & chú & 391 & con & 853 \\
\hline 21 & đây & 519 & đã & 1,620 & chúng & 518 & còn & 107 \\
\hline 22 & đến & 1,168 & đầu & 418 & có & 1,573 & của & 470 \\
\hline 23 & để & 1,180 & đảng & 500 & cô & 655 & cũng & 135 \\
\hline 24 & di & 594 & đại & 424 & con & 2,232 & đá & 97 \\
\hline 25 & định & 575 & đến & 722 & còn & 493 & đã & 259 \\
\hline 26 & điều & 498 & để & 897 & công & 308 & đầu & 92 \\
\hline
\end{tabular}


APPENDIX B (Continued)

\begin{tabular}{|c|c|c|c|c|c|c|c|c|}
\hline & Adult VN & Freq & Adult $O$ & Freq & Child VN & Freq & Child O & Freq \\
\hline 27 & đó & 952 & điều & 424 & của & 1,049 & đang & 120 \\
\hline 28 & đồng & 647 & đó & 609 & cũng & 555 & đâu & 97 \\
\hline 29 & động & 663 & dồng & 649 & cùng & 390 & đây & 117 \\
\hline 30 & được & 2,041 & động & 450 & đã & 908 & đến & 232 \\
\hline 31 & do & 523 & được & 1,200 & đầu & 392 & để & 145 \\
\hline 32 & gia & 652 & do & 749 & dang & 454 & di & 385 \\
\hline 33 & hàng & 528 & gia & 537 & đâu & 308 & đó & 286 \\
\hline 34 & hiện & 766 & giới $i$ & 432 & đến & 1,051 & được & 278 \\
\hline 35 & học & 1,131 & hà & 470 & để & 696 & $\mathrm{em}$ & 152 \\
\hline 36 & hội & 549 & hai & 400 & đi & 1,380 & gấu & 235 \\
\hline 37 & ho'n & 686 & họ & 419 & đó & 520 & gì & 147 \\
\hline 38 & khi & 1,117 & hội & 872 & đượcc & 1,087 & giờ & 107 \\
\hline 39 & không & 2,104 & khi & 650 & em & 401 & hai & 99 \\
\hline 40 & là & 2,590 & không & 1,482 & gì & 445 & hỏi & 136 \\
\hline 41 & lại & 839 & là & 2,107 & hai & 425 & họ & 105 \\
\hline 42 & làm & 1,109 & lại & 638 & hoa & 353 & khi & 209 \\
\hline 43 & lên & 482 & làm & 629 & hôm & 377 & không & 505 \\
\hline 44 & lý & 536 & lên & 414 & khi & 644 & là & 475 \\
\hline 45 & mà & 634 & mà & 562 & không & 1,654 & lại & 208 \\
\hline 46 & $\operatorname{minh}$ & 538 & một & 1,451 & là & 1,204 & làm & 203 \\
\hline 47 & mới & 639 & năm & 847 & lấy & 341 & lên & 241 \\
\hline 48 & một & 2,419 & nam & 1,029 & lại & 1,034 & lớn & 144 \\
\hline 49 & năm & 1,081 & này & 757 & làm & 795 & mà & 96 \\
\hline 50 & nam & 662 & ngày & 684 & lên & 1,012 & màu & 102 \\
\hline 51 & nay & 520 & người & 1,364 & lúc & 422 & mẹ & 249 \\
\hline 52 & này & 1,146 & Nguyễn & 428 & mà & 514 & mình & 191 \\
\hline 53 & ngày & 737 & nhà & 854 & mẹ & 839 & một & 706 \\
\hline 54 & người & 1,937 & nhân & 874 & mình & 729 & nào & 108 \\
\hline 55 & nhà & 916 & nhiều & 449 & một & 2,213 & này & 128 \\
\hline 56 & nhất & 522 & nhur & 765 & nàng & 345 & ngày & 137 \\
\hline 56 & nhân & 633 & những & 1,083 & nào & 443 & nghe & 88 \\
\hline 58 & nhiều & 1,000 & nhu'ng & 429 & này & 450 & người & 289 \\
\hline 59 & nhur & 996 & nội & 552 & ngày & 481 & nhà & 235 \\
\hline 60 & những & 1,655 & nói & 437 & nghe & 381 & nhảy & 90 \\
\hline 61 & nhưng & 805 & nướcc & 898 & ngườ'i & 1,015 & nhiề & 100 \\
\hline 62 & nước & 888 & ơ & 803 & nhà & 1,004 & nhì & 99 \\
\hline 63 & $\mathrm{o}^{3}$ & 1,328 & ông & 710 & nhìn & 351 & nhỏ & 90 \\
\hline 64 & ông & 813 & phải & 587 & nhur & 536 & nhur & 155 \\
\hline 65 & phải & 964 & pháp & 449 & như'ng & 637 & những & 246 \\
\hline 66 & phát & 540 & qua & 409 & nhưng & 637 & nhurng & 192 \\
\hline 67 & qua & 505 & quan & 427 & nó & 639 & nó & 194 \\
\hline 67 & quan & 603 & quốc & 950 & nói & 955 & nói & 367 \\
\hline 67 & quốc & 537 & quyền & 723 & กũ’a & 321 & nũra & 88 \\
\hline 70 & $\mathbf{r a}$ & 968 & ra & 802 & nước & 398 & ơ & 207 \\
\hline 71 & rất & 678 & sau & 468 & $o^{\beta}$ & 598 & ông & 112 \\
\hline 72 & sau & 585 & sẽ & 478 & ông & 927 & phải & 164 \\
\hline 73 & sẽ & 934 & số & 553 & phải & 590 & qua & 86 \\
\hline 74 & sinh & 735 & sụp & 670 & quá & 311 & quá & 85 \\
\hline 75 & số & 759 & tại & 712 & ra & 1,179 & ra & 245 \\
\hline 76 & sụ & 774 & tháng & 471 & rất & 452 & rất & 140 \\
\hline 77 & tại & 995 & thành & 697 & rồi & 895 & rồi & 221 \\
\hline 78 & thành & 901 & thệ̉ & 642 & sao & 304 & sao & 92 \\
\hline 79 & thế & 711 & thể & 475 & sau & 429 & sau & 109 \\
\hline 80 & thế & 948 & theo & 478 & $\mathbf{s e ̃}$ & 602 & sẽ & 126 \\
\hline 80 & theo & 745 & thì & 463 & ta & 782 & ta & 281 \\
\hline 82 & thi & 635 & thi' & 478 & thấy & 953 & thấy & 195 \\
\hline 83 & thì & 736 & tôi & 979 & thật & 322 & thật & 100 \\
\hline
\end{tabular}


APPENDIX B (Continued)

\begin{tabular}{rlrlrllllr}
\hline & Adult VN & Freq & Adult $O$ & Freq & Child VN & Freq & Child O & Freq \\
\hline 84 & thời & 497 & trên & 630 & thế & 566 & thế & 119 \\
85 & thông & 485 & trong & 1,649 & thì & 683 & thể & 133 \\
86 & tôi & 1,137 & trung & 527 & thỏ & 417 & thì & 139 \\
87 & trên & 761 & trước & 456 & tiếng & 317 & tiếng & 109 \\
87 & trong & 1,979 & từ & 696 & tìm & 320 & tới & 98 \\
87 & trung & 600 & tụ̣ & 546 & tôi & 615 & tôi & 429 \\
87 & trước & 487 & và & 2,956 & trên & 478 & trên & 148 \\
91 & trường & 903 & văn & 502 & trong & 729 & trong & 294 \\
92 & từ & 971 & vào & 877 & từ & 434 & từ & 107 \\
93 & và & 3,198 & về & 780 & và & 1,608 & tường & 85 \\
94 & vào & 988 & vì & 523 & và̀o & 911 & và & 881 \\
95 & về & 1,069 & việc & 469 & về & 714 & vậy & 115 \\
96 & vì & 577 & việt & 878 & vì & 309 & vào & 202 \\
97 & việc & 820 & viền & 405 & với & 623 & về & 156 \\
98 & việt & 632 & với & 1,040 & vừa & 419 & với & 192 \\
99 & viền & 528 & vụ & 451 & vua & 410 & vừa & 98 \\
100 & với & 1,657 & 2006 & 514 & xuống & 413 & xuống & 116 \\
\hline
\end{tabular}

(Manuscript received March 3, 2007;

revision accepted for publication April 11,2007.) 